Archives of Agriculture and Environmental Science

\title{
Growth of Agathis dammara (Lamb. Rich.) seedling on gold tailing with addition of coconut shell charcoal and compost
}

\author{
Basuki Wasis*, Bayu Winata and Rafika Andriani \\ Department of Silviculture, Faculty of Forestry, Bogor Agricultural University, Bogor 16680, West Java, INDONESIA \\ "Corresponding author's E-mail: basuki_wasis@yahoo.com
}

\section{ARTICLE HISTORY \\ Received: 30 April 2018 \\ Revised received: 20 May 2018 \\ Accepted: 28 May 2018}

\section{Keywords}

Agathis dammara

Coconut shell charcoal

Compost

Seedling growth

Soil characteristics

Tailing

\begin{abstract}
Tailing produced by gold mining activities may cause environmental damage, such as decreasing of soil fertility and endangering ecosystem. Tailing also can decrease the soil chacaracteristics and its fertility. Thus, it is not able to carry the plant growth as well. The addition of coconut shell charcoal and compost on tailing may improve the condition of soil properties (physical, chemical, and biological) and its fertility. Agathis dammara (Lamb. Rich.) is one of pioneer tree species that can be potentially used on revegetation process in post mining land. This research was carried out to assess the effect of adding coconut shell charcoal and compost on the growth of A. dammara seedling in tailing medium. This research uses complete random design (CRD) factorial. The result of this research shows that giving coconut shell charcoal and compost manure does not have significant effect to all parameter viz height, diameter, total wet weight (TWW), total dry weight (TDW), and root-shoot ratio (RSR) of A. Dammara. The addition of coconut shell charcoal and compost gave the significant effects on total dry weight (TDW) of A. dammara seedling. The best treatment was the addition of $0 \mathrm{~g}$ coconut shell charcoal and $20 \mathrm{~g}$ compost (AOB1). Generally, the addition of coconut shell charcoal and compost could improve the soil characteristics and support the growth of the A. dammara seedling on tailing medium.
\end{abstract}

C2018 Agriculture and Environmental Science Academy

Citation of this article: Wasis, B., Winata, B. and Andriani, R. (2018). Growth of Agathis dammara (Lamb. Rich.) seedling on gold tailing with addition of coconut shell charcoal and compost. Archives of Agriculture and Environmental Science, 3(2): 131-136, https://dx.doi.org/10.26832/24566632.2018.030205

\section{INTRODUCTION}

The natural resources is divide into two catergories. Those are the renewable natural resources and non-renewabl (depletable) natural resources. Non-renewabale natural resouce is the natural resource which does not have ability on biologically regeneration or can not renew if its sources have completed in the nature. It is formed by the geological process with a long time (period) to be available again and ready to be used (Fauzi, 2006). The mining comodity is one of the non-renewable natural resources. In the extraction process to split the mining mineral (mineral target) can produce the waste in environment, namely tailing. Tailing as a mining waste is able to causing serious problems in the environment, such as pollution in ecosystem and land (soil) degredation. Tailing has specific charcateristics, such as marginal (poor on soil nutrients) and containing heavy metals which may defile the environment (Setyaningsih et al., 2012; Setiadi and Cakyanti, 2014; Winata et al., 2016).

However, the post mining land must be rehabilitated to be safe, stable, and productive ecosystem. Revegetation is one of post land mining rehabilitation steps. Species matching (species election) and the soil improvement are the important part to achieve the success of revegetation. Thus, the tailing charactersitics improvement is the important step to support the growth of the plants. Related to species election, A. dammara (Agathis dammara Lamb. Rich.) is one of the pioneer tree species which is potentially used as revegetation plants in tailing medium (Renden et al., 2006; Danu et al., 2011; Uthbah et al., 2017). The tailing improvement can be conducted by the addition of coconut shell charcoal and compost. The addition of coconut shell charcoal and compost aim to improving the soil (medium) structure, increasing macro and micro nutrient, and decreasing heavy metals contents (Yuniwati et al., 2012; Wasis and Istantini, 2013; Winata et al., 2016). The aims of this study were to analyze the growth of A. dammara seedling in the tailing and to analyze the influence of coconut shell charcoal and compost increament toward the A. dammara seedling growth in the tailing. 


\section{MATERIALS AND METHODS}

\section{Time and location}

This research was conducted from June-September of 2015 in the greenhouse of Silviculture Division and Forest Influence Laboratory of Department of Silviculture, Faculty of Forestry, Bogor Agricultural University (IPB). Tailing was taken from the gold mining area in Pongkor, Bogor, West Java, Indonesia. The tailing properties analyze was conducted in Laboratory of Soil Science and Land Resources, Faculty of Agriculture IPB.

\section{Materials and tools}

Materials used in this study were Agathis dammara (Lamb. Rich.) seedling (age : 3 month) which has $20 \mathrm{~cm}$ of height, gold mining tailing, coconut shell charcoal, and compost. Tools used in this study were digital scale, ruler $(60 \mathrm{~cm})$, caliper, polybag $(20 \times 20$ $\mathrm{cm}$ ), digital camera, tallysheet, writing tools, oven.

\section{Medium preparation and plantation}

Planting medium used was tailing of the gold mining waste. Tailing was weighed as $1 \mathrm{~kg}$, then placed into the polybag. After that, coconut shell charcoal and compost were added and mixed with tailing untill homogenous. The doses of coconut shell charcoal were $0,25,50,75$, and $100 \mathrm{~g}$. In other hand, the doses of compost were $0,20,40$, and $60 \mathrm{~g}$. After the planting mediums were ready, A. dammara seedlings were planted in the medium in polybag.

\section{Maintenance}

A. dammara seedlings maintenance was conducted through watering (pouring the water) in the morning and evening during four months.

\section{Data collection}

Data collection was conducted every week in the period of June -September 2015. The variables observed were height and diameter. In the last week A. dammara seedlings were harvested. After that, those were weighed to know the wet weight. Then, seedlings were dried off in the oven at $80^{\circ} \mathrm{C}$ as long as 24 hours (Wasis and Fathia, 2011; Wasis and Angga, 2017). After that, $A$. dammara seedlings were weighed again to know the dry weight. In other hand, two samples of soil / tailing (planting medium) were analyzed to know the soil characteristics. The two samples of these medium were soil / medium with control treatment and the best treatment which gave the best growth prefromance of A. dammara.

\section{Experimental design and data analyze}

Experimental design used was factorial completely randomized design with two factors. Factor $A$ was coconut shell charcoal with 5 doses $\left(A_{0}=0, A_{1}=25, A_{2}=50, A_{3}=75, A_{4}=100 \mathrm{~g}\right)$ and factor $B\left(B_{0}=0, B_{1}=20, B_{2}=40, B_{3}=60 \mathrm{~g}\right)$ was compost with 4 doses and further the combinations $A_{0} B_{0}, A_{0} B_{1}, A_{0} B_{2}, A_{0} B_{3}, A_{1} B_{0}, A_{1} B_{1}$, $A_{1} B_{2}, A_{1} B_{3}, A_{2} B_{0}, A_{2} B_{1}, A_{2} B_{2}, A_{2} B_{3}, A_{3} B_{0}, A_{3} B_{1}, A_{3} B_{2}, A_{3} B_{3}, A_{4} B_{0}$, $A_{4} B_{1}, A_{4} B_{2}$ and $A_{4} B_{3}$ were used for the treatments. Each treatments were conducted with four repetitions. Obtained data based on measurement of height, diameter, total wet weight (TWW), total dry weight (TDW), and Root-shoot ratio (RSR) was analyzed by using linear model (Mattjik and Sumertajaya, 2013; Stell and Torries, 1991; Wibisono, 2009). Only if there is significant effect, Duncan's Multiple Range Test will be measured for getting further statistic data.

\section{RESULTS AND DISCUSSION}

The growth of $A$. dammara seedling in the tailing

The influence of coconut shell charcoal and compost increment toward A. dammara seedling growth (height, diameter, total wet weight / TWW, total dry weight / TDW, and root-shoot ratio) were shown in Table 1.

Treatment of coconut shell charcoal increment had not significantly effect toward growth of height, diameter, also biomass (TWW and TDW), and root-shoot ratio. These facts were similar with treatment of compost increment toward A. Dammara seedling growth. However, the interaction between the increament of coconut shell charcoal and compost had a significantly effect on TDW. Growth is the increment of plant dimension, both height or diameter. The vertical growth (height) is the primary grwoth of the plant. It call as initial growth, while the horizontal growth (diameter) is the secondary growth. The abiotic (environmental) factors and the genetic factor (intern) have influences toward the height dan diameter growth, such as soil nurtient content, soil humadity, soil porosity, soil structure, soil acidity $(\mathrm{pH})$, sunlight, and genetic characteristic among the plants whitin one species that give various expressions in the plant's growth. Figure 1 was showing influence of coconut shell charcoal and compost addition on height and diameter of A. dammara seedling.

Coconut shell charcoal increment gave an influence on the growth of height and diameter. The highest growth of A. dammara on the height and diameter were $7.83 \mathrm{~cm}$ and $0.17 \mathrm{~cm}$, respectively. In other hand, compost addition also gave effect toward the growth of A. dammara on the height and diameter. The highest growth by compost treatment on the height and diameter were $7.5 \mathrm{~cm}$ and $0.15 \mathrm{~cm}$, respectively. However coconut shell charcoal and compost increment were not significant to the height and diameter of A. dammara seedling which was planted in the tailing. This fact indicated that $A$. dammara was an adaptive species where could growth in the marginal land, such as tailing medium. In other hand, coconut shell charcoal and compost had important role to support the growth of $A$. dammara as well. Figure 2 was showing effect of coconut shell charcoal and compost increment toward the growth of biomass of $A$. dammara seedling in tailing.

The highest TWW of A. dammara seedling (10.24 g) was shown by $25 \mathrm{~g}$ coconut shell charcoal addition. Beside that, the addition of $20 \mathrm{~g}$ compost was also giving the higest TWW growth of $A$. dammara seedling (10.31 g). However the treatment of coconut shell charcoal and compost increment were not significantly different toward A. dammara seedling biomass which were planted in the tailing. Dry weight is able to show the plant's productivity, 
due to $90 \%$ of photosynthesis product was found in the dry weight form (Gardner et al., 1991). Table 2 showed that the best treatments to support the growth of total dry weight of $A$. dammara in the tailing medium were $A_{0} B_{1}, A_{1} B_{3}$, and $A_{1} B_{2}$. It indicated that the addition of coconut shell charcoal from $0 \mathrm{~g}$ to $25 \mathrm{~g}$ and the addition of compost about $20 \mathrm{~g}, 40 \mathrm{~g}$, to $60 \mathrm{~g}$ could support the growth of $A$. dammara seedling as well in the tailing medium. The interaction treatments (coconut shell charcoal and compost) gave significant influence toward TDW of $A$. dammara (Table 2). Based on this study, it was kwown that the treatment with $0 \mathrm{~g}$ coconut shell charcoal and $20 \mathrm{~g}$ compost increment $\left(A_{0} B_{1}\right)$ gave the raising of the TDW (12.44\% toward the control). Beside that, the tretament of $25 \mathrm{~g}$ coconut shell charcoal and $0 \mathrm{~g}$ compost $\left(A_{1} B_{0}\right)$ were showing the lowest growth of total dry weight (-41.45\% toward control).

Charcoal is a porous material which produced throught out pyrolysis process or organic matter (containing carbon) burning process. Charcoal contain dust, water, nitrogen, and sulfur. The benefits of charcoal were to increasing organic matter $(C / N)$ in the soil, improving water and air circulation in the soil. Thus it will stimulate the growth of the root (Gusmailina et al., 2002). Beside that, charcoal also is able to hold soil nutrient, and support the soil biology's life. Charcoal will release nutrient for the plant slowly appropriate to the plant necessary. Thus charcoal can support plant to growing up in the marginal soil, such as tailing. Cahrcoal has function as a soil amendment material such as improving the soil charactersitics (soil physic, soil chemical, and soil biology), absorbing toxic substance in the tailing, and also stimulating the root growth (Darwo and Sugiari, 2008; Wasis and Noviani, 2010; Wasis and Istantini, 2013).

Wasis and Istantini (2013) said that root-shoot ratio is needed to know the growth parity between shoot as a location for photosynthesis and root as a location for water and nutrient absorbtion. Figure 3 showed root-shoot ratio of A. dammara in several treatments of coconut shell charcoal and compost increment which planted in the tailing.

Figure 3 showed the average of root-shoot ratio of $A$. dammara. The higest root-shoot ratio was shown by the $A_{0} B_{1}$ treatment (8.34). It means that the addition of $0 \mathrm{~g}$ coconut shell charcoal and $20 \mathrm{~g}$ compost could support the shoot growth of the $A$. dammara. $A_{0} B_{1}$ treatment caused the shoot growth of th $A$. dammara higer than the root growth. This phenomenon perhaps due to the compost increment. In other hand, the lowest rootshoot ratio was shown by the $A_{1} B_{0}$ treatment (2.98). $A_{1} B_{0}$ treatment was the addition of $25 \mathrm{~g}$ coconut shell charcoal and 0 g compost. Without compost, the root-shoot ratio of A. dammara was decrease. The low value of root-shoot ratio was showing that the root growth of the A. dammara lower than the shoot root. Without compost, A. dammara's root might be growing up more than there was a compost in the soil. This phenomenon probably due to A. dammara's root was stimulated by the lack of nutrient. These facts indicated that compost palyed an important role toward the A. dammara growth, which planted in the tailing. At least, compost is one of organic matter that contain essential components for the plant (Munawar, 2011). This study shows that charcoal giving has caused excess nutrients to be absorbed. The existing nutrients are absorbed in the charcoal so that they become unavailable to the plant.

\section{Soil nutrient analysis}

Soil nutrient analysis as a supporting data was conducted in the end of the research. The soil samples taken for the analysis process were the soil (medium) which given $A_{0} B_{0}$ treatment (control) and $A_{1} B_{2}$ (treatment that gave the best growth of the height and the diameter) (Table 3 ).

Charcoal (25 g) and compost (40 g) or $A_{1} B_{2}$ treatment could increase soil $\mathrm{pH}$ as 0.63 to be 7.40 . Beside that these treatmnet also increased cation change capacity (CEC) from $2.39 \mathrm{me} / 100 \mathrm{~g}$ to $4.83 \mathrm{me} / 100 \mathrm{~g}$. The exsistence of organic matter and clay in the soil were rewarding to the CEC, and it would increase the soil fertility (Hardjowigeno, 2003; Tan 1994; Phillip et al., 2015). Coconut shell charcoal and compost increment $\left(A_{1} B_{2}\right)$ also could increase the soil nutrient availability. The soil analysis showed that these treatments increased several elements, such as $\mathrm{C}(1.62$ \%), N (0.04\%), P (3.84 ppm), K (0.65 me/100g) Ca (8.89 me/100 g), and $\mathrm{Mg}(0.10 \mathrm{me} / 100 \mathrm{~g})$. This study showed that the coconut shell charcoal and compost increment could increased soil characteristics, such as improved soil $\mathrm{pH}, \mathrm{CEC}$, soil organic, also soil nutrient which all of those were very important to support the growth of plant. In other hand, in this tsudy showed that the increment of coconut shell charcoal and compost was not significantly toward the growth of A. dammara, except the TDW parameter. This phenomenon might cause of (1). the doses of the treamtments were to low, or (2). A. dammara was an adaptive species which had good performance and adaptability to growth in the tailing (marginal medium). However, basically oragnic fertilizer such as charcoal and compost have low nutrient content relatively, but this fertilizer has a special role to improve the soil characteristics (Hardjowigeno, 2003, Munawar, 2011; Wasis dan Fathia, 2011).

Table 1. The effect of coconut shell charcoal and compost increment on A. dammara seedling growth.

\begin{tabular}{lccc}
\hline \multirow{2}{*}{ Parameter } & & Treatment & \\
\cline { 2 - 4 } & Charcoal & Compost & Charcoal×Compost \\
\hline Height & $0.765^{\text {tn }}$ & $0.864^{\text {tn }}$ & $0.052^{\text {tn }}$ \\
Diameter & $0.297^{\text {tn }}$ & $0.941^{\text {tn }}$ & $0.409^{\text {tn }}$ \\
Total wet weight & $0.376^{\text {tn }}$ & $0.890^{\text {tn }}$ & $0.057^{\text {tn }}$ \\
Total dry weight & $0.173^{\text {tn }}$ & $0.984^{\text {tn }}$ & $0.026^{*}$ \\
Root-shoot ratio & $0.750^{\text {tn }}$ & $0.071^{\text {tn }}$ & $0.534^{\text {tn }}$ \\
\hline
\end{tabular}

Numbers in the table were significant value. ${ }^{*}=$ treatment signifiacantly affect, on confidence interval $95 \%(\mathrm{Pr}<\mathrm{F})$. tn $=$ treatment no significant affect, on confidence interval 95\% ( $\mathrm{Pr}>\mathrm{F})$. 
Table 2. Duncan test result of coconut shell charcoal and compost increment toward the total dry weight of A. dammara.

\begin{tabular}{|c|c|c|}
\hline Treatment & Average of total dry weight (g) & Increasing toward control (\%) \\
\hline $\mathrm{A}_{0} \mathrm{~B}_{0}$ & $3.86 \mathrm{ab}$ & 0.00 \\
\hline$A_{0} B_{1}$ & $4.34 \mathrm{c}$ & 12.44 \\
\hline$A_{0} B_{2}$ & $2.30 \mathrm{bc}$ & -40.41 \\
\hline$A_{0} B_{3}$ & $3.06 \mathrm{abc}$ & -20.73 \\
\hline$A_{1} B_{0}$ & $2.26 \mathrm{a}$ & -41.45 \\
\hline$A_{1} B_{1}$ & $2.97 \mathrm{abc}$ & -23.06 \\
\hline$A_{1} B_{2}$ & $3.59 \mathrm{abc}$ & -6.99 \\
\hline$A_{1} B_{3}$ & $3.65 a b c$ & -5.44 \\
\hline$A_{2} B_{0}$ & $3.14 a b c$ & -18.65 \\
\hline$A_{2} B_{1}$ & $2.93 \mathrm{abc}$ & -24.09 \\
\hline$A_{2} B_{2}$ & $2.95 a b c$ & -23.58 \\
\hline $\mathrm{A}_{2} \mathrm{~B}_{3}$ & $2.35 \mathrm{bc}$ & -39.12 \\
\hline$A_{3} B_{0}$ & $2.81 \mathrm{abc}$ & -27.20 \\
\hline$A_{3} B_{1}$ & $2.76 \mathrm{bc}$ & -28.50 \\
\hline$A_{3} B_{2}$ & $3.51 \mathrm{abc}$ & -9.07 \\
\hline$A_{3} B_{3}$ & $3.47 \mathrm{abc}$ & -10.10 \\
\hline $\mathrm{A}_{4} \mathrm{~B}_{0}$ & $2.86 a b c$ & -25.91 \\
\hline$A_{4} B_{1}$ & $2.38 \mathrm{bc}$ & -38.34 \\
\hline$A_{4} B_{2}$ & $2.87 \mathrm{abc}$ & -25.65 \\
\hline$A_{4} B_{3}$ & $2.39 \mathrm{bc}$ & -38.08 \\
\hline
\end{tabular}

Number followed by the same letter showing treatment significant difference at $95 \%$ confidence level. Charchoal doses: $A_{0}=0 \mathrm{~g}, A_{1}=25 \mathrm{~g}, A_{2}=50 \mathrm{~g}$, $A_{3}=75 \mathrm{~g}$, and $A_{4}=100 \mathrm{~g}$. Compost doses: $B_{0}=0 \mathrm{~g}, B_{1}=20 \mathrm{~g}, B_{2}=40 \mathrm{~g}$, and $B_{3}=60 \mathrm{~g}$.

Table 3.The characteristic of planting medium (tailing) of A. Dammara.

\begin{tabular}{|c|c|c|c|c|c|}
\hline Parameter & Treatment $\left(\mathrm{A}_{0} \mathrm{~B}_{0}\right)$ & Criteria $^{*}$ & Treatment $\left(\mathrm{A}_{1} \mathrm{~B}_{2}\right)$ & Criteria $^{*}$ & Alteration \\
\hline Sand (\%) & 78.16 & - & 52.32 & - & \\
\hline Dust (\%) & 18.00 & - & 41.63 & - & \\
\hline Clay (\%) & 3.84 & - & 6.05 & - & \\
\hline $\mathrm{pH}$ & 6.77 & Netral & 7.40 & Netral & +0.63 \\
\hline CEC (me/100g) & 2.39 & Very low & 4.83 & Very low & +2.44 \\
\hline C-org (\%) & 0.07 & Very low & 1.69 & Low & $+1,62$ \\
\hline N-Total (\%) & 0.03 & Very low & 0.07 & Very low & $+0,04$ \\
\hline$P(p p m)$ & 3.22 & Very low & 7.06 & Very low & +3.84 \\
\hline $\mathrm{Ca}(\mathrm{me} / 100 \mathrm{~g})$ & 22.05 & Very high & 30.94 & Very high & +8.89 \\
\hline $\mathrm{Mg}(\mathrm{me} / 100 \mathrm{~g})$ & 0.83 & Low & 0.93 & Low & +0.10 \\
\hline $\mathrm{K}(\mathrm{me} / 100 \mathrm{~g})$ & 0.24 & Low & 0.89 & High & +0.65 \\
\hline $\mathrm{Na}(\mathrm{me} / 100 \mathrm{~g})$ & 0.12 & High & 1.12 & Very high & +1.00 \\
\hline $\mathrm{Al}(\mathrm{me} / 100 \mathrm{~g})$ & $\mathrm{Tr}$ & - & $\mathrm{Tr}$ & - & \\
\hline $\mathrm{Fe}(\mathrm{ppm})$ & $\mathrm{Tr}$ & - & 16.04 & - & +16.04 \\
\hline $\mathrm{Cu}(\mathrm{ppm})$ & 0.03 & - & 3.07 & - & +3.04 \\
\hline $\mathrm{Zn}(\mathrm{ppm})$ & $\mathrm{Tr}$ & - & 5.75 & - & +5.75 \\
\hline Mn (ppm) & 41.33 & - & 5.28 & - & -36.05 \\
\hline
\end{tabular}

" = Soil characteristic criteria assesment by Soil Research Center (Soil Research Center) (Pusat et al.,1983).

Height growth (cm)

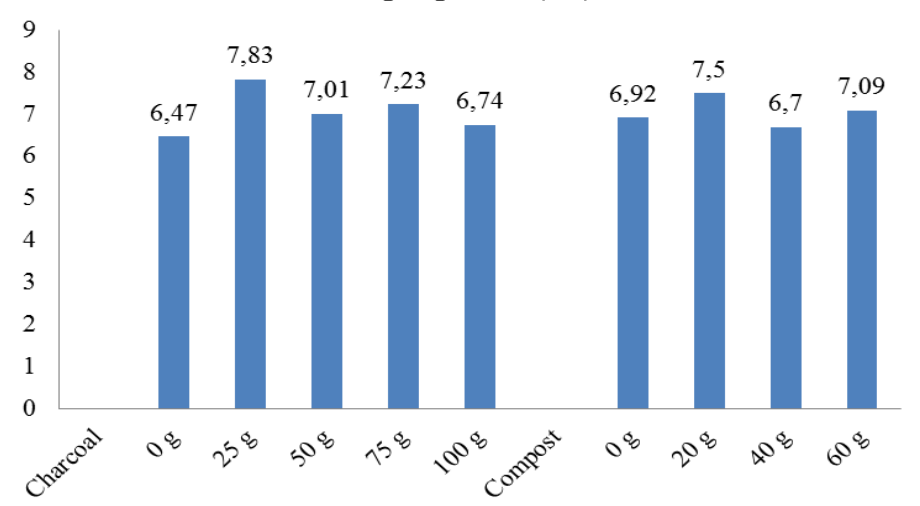

Diametr growth (cm)

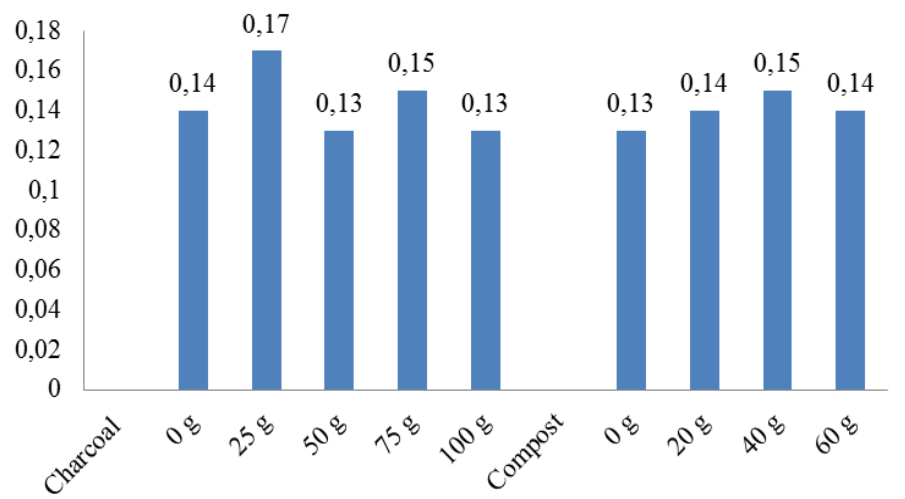

Figure 1. Effect of coconut shell charcoal and compost increment toward the growth of height and diameter of A. dammara seedling in tailing. 
Total wet weight (g)

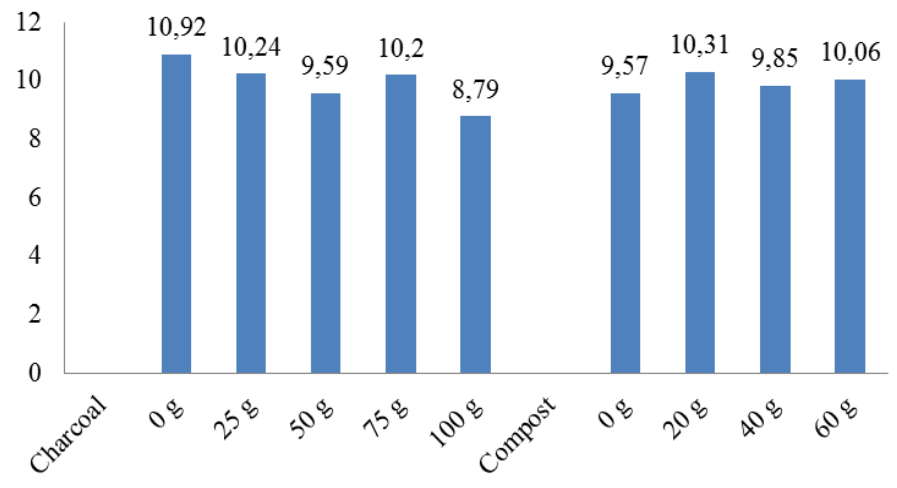

Figure 2. Effect of coconut shell charcoal and compost increment toward the growth of biomass of A. dammara seedling in tailing.

\section{Conclusion}

The addition of coconut shell charcoal and compost on the tailing gave significant influence toward TDW of A. dammara seedling, that was the treatment of the addition of $0 \mathrm{~g}$ coconut shell charcoal and $20 \mathrm{~g}$ compost). In other hand, the addition coconut shell charcoal and compost could improve the tailing characteristics, so this condition chould support the growth of $A$. dammara as well, generally.

\section{ACKNOWLEDGEMENTS}

Researchers would like to appreciate Forest Ecology Laboratory, Forest Influence Laboratory of BAU/IPB, and the chairman of Deparment of Silvicultre BAU/IPB for their help and support to complete this research.

Open Access: This is open access article distributed under the terms of the Creative Commons Attribution License, which permits unrestricted use, distribution, and reproduction in any medium, provided the original author(s) and the source are credited.

\section{REFERENCES}

Danu, Subiakto, A. and Putri K.P. (2011). Shoot cutting trial of damar (Agathis loranthifolia Salisb.) at some media and growth regulator. Journal of Forest and Nature Conservation Research, 8 (3): 245-252, http://forda-mof.org/ files/05.Stek_pucuk_damar-Final_.pdf

Darwo and Sugiarti (2008). The effect of spore powder doses of Scleroderma citrinum persoon mycorrhizal fungi and media composition on the pine growth in nursery. Journal of Forest and Nature Conservation Research, 5(5): 461-472, http:// ejournal.forda-mof.org/ejournal-litbang/index.php/JPHKA/ article/view/1180/1102

Fauzi, A. (2006). Natural Resources and Environment Economics. PT. Gramedia Pustaka Utama.Jakarta

Gardner, F.P., Pearce, R.B. and Mitchell, R.L. (1991). Physiology of crop plants. UI Press. Jakarta

Gusmailina, G., Pari, S. and Komaryati (2002). Development of charcoal use for land rehabilitation. Buletin Penelitian dan

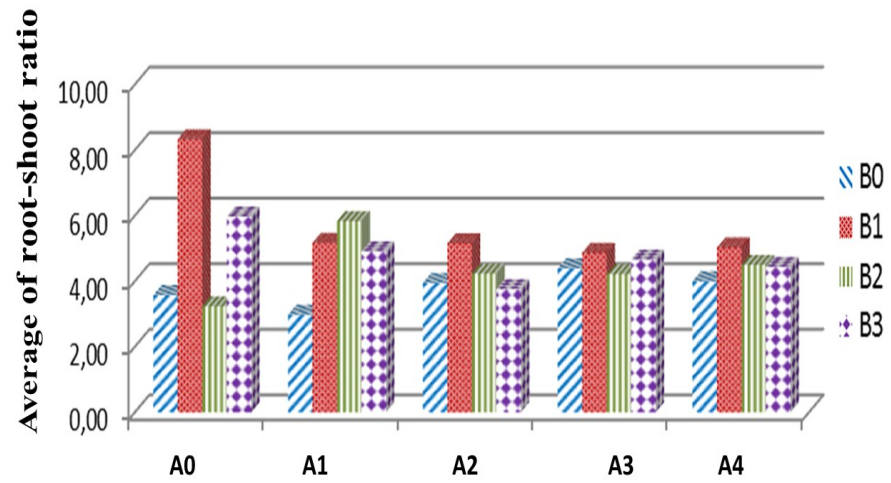

Figure 3. The average of root-shoot ratio of A. dammara seedling in the several treatment combinations of the increment of coconut shell charchoal (A) and compost (B).

Pengembangan Kehutanan, 4 (1):21-30.

Hardjowigeno, S. (2003). Science of Soil. Akademia Akapressindo. Jakarta

Mattjik, A.A. and Sumertajaya, I.M. ( 2013). Experimental Design with SAS Applications and Minitab. IPB Press. Bogor.

Munawar, A. (2011). Soil Fertility and Plant Nutrition. Bogor (ID) IPB Press. pp. 240.

Phillip, W.D., Mansur, I. and Wasis, B. (2015). Establishment of Africa Red Mahagony (Khaya anthoteca) pre-inoculated with arbuscular mycorrhizae fungi (AMF) and compost application on an ex-coal mined site. American Journal of Agriculture and Forestry, 3(2) 36-46, https:// doi.org/10.11648/j.ajaf.20150302.15

Pusat, P.T. [Soil Research Center] (1983). Balai Penelitian dan Pengembangan Pertanian Departemen Pertanian Bogor [Indonesian Center for Agricultural Research and Development Agriculture Department Bogor] Kriteria Penilaian Data Sifat Analisis Kimia Tanah [Criteria Assessment Data Properties of Soil Chemistry Analysis].

Renden, R. Allo, M.K. and Suhartati, S. (2006). Combining natural regeneration of Aghatis dammara (Lambert) L. C. Rich. with planted Theobroma cacao Linn. at lessproduction land of Malili South Sulawesi. Journal of Forest and Nature Conservation Research, 3(3): 215-223, http://ejournal.fordamof.org/ejournal-litbang/index.php/JPHKA/article/ view/3063/0

Setiadi, Y. and Cakyayanti (2014). Study result of research about the growth rate of tree species in post mining area in Indonesia. Journal of Tropica Silviculture Science and Technology, 05(2): 91-96.

Setyaningsih, L., Setiadi, Y., Soepandi, D. and Budi, S.W. (2012). Organic acic charasteristic and tolerance of sengon (Paraserianthes falcataria L Nielsen) to lead. JMHT 18 (3): 177-183, https://doi.org/10.7226/jtfm 18.2.177

Stell, R.G.D. and Torries, J. (1991). Statistical Principles and Procedures, A Biometric Approach. 2nd Edition, Mc Graw Hill International Book Co., Singapore City.

Tan, K.H. (1994). Enviromental Soil Science. Marcel Dekker Inc. New York, USA, pp. 304.

Uthbah, Z. Sudiana, E. and Yani, E. (2017). Analysis of biomass and carbon stocks in various ages of damar stand (Agathis 
damara Lamb. Rich) in $\mathrm{KPH}$ Banyumas Timur. Scipta Biologica, 4(2): 119-124, https://media.neliti.com/media/ publications/169248-ID-analisis-biomasa-dan-cadangankarbon-pad.pdf

Wasis, B. and Andika, A. (2017). Growth response of mahagony seedling (Swietenia macrophylla King.) to addition of coconut shell charcoal and compost on ex-sand mining site of West Java Province in Indonesia. Archives of Agriculture and Enviromental Science, 2(3): 238-243, https:// www.aesacademy.org/journal/volume2/issue3/AAES-0203-018.pdf

Wasis, B. and Fathia, N. (2011). Growth of gmelina seedlings with various doses of compost fertilizers on the media of former ground gold mine. Journal of Tropical Forest Management, 17 (1): 29-33.

Wasis, B. and Istantini, A. (2013). Application of coconuts shells charcoal and cow feces (bokhasi) on the growth of jabon (Anthocephalus cadamba Miq.) seedling at gold mine tailings medium. Journal of Tropica Silviculture Science and Technology, 04(2): 82-87, http://id.portalgaruda.org/index.php? ref=browse\&mod=viewarticle\&article $=282014$

Wasis, B. and Noviani, D. (2010). Influence of NPK fertilizer and compost on growth seedling jabon (Anthocephalus cadamba Roxb Miq.) gold mining tailing. Journal of Agricultural Science Indonesia, 12(1): 14-19

Wibisono, Y. (2009). Statistics Method. Gadjah Mada University Press. Yokyakarta. pp. 529-603

Winata, B., Wasis, B. and Setiadi, Y. (2016). Adaptability study of samama (Anthocephalus macrophyllus) on several lead (Pb) level. Journal of Natural Resources and Environmental Management, 6 (2): 210-216, https://doi.org/10.19081/ jpsl.2016.6.2.211

Yuniwati, M., Iskandar, F. dan Padulemba, A. (2012). Optimization of the condition of composting process from waste by fermentation using EM4. Journal of Technology, 5 (2): 172181. 